\title{
THE ROLE OF SOCIAL MEDIA ON THE STUDENT'S ENGLISH LEARNING ACHIEVEMENT
}

\author{
$1^{\text {st }}$ Ade Noviyanti \\ English Language Teaching Department \\ Universitas Panca Sakti Bekasi \\ adenoviyanti99@gmail.com
}

\author{
$2^{\text {nd }}$ Franscy \\ English Language Teaching Department \\ Universitas Panca Sakti Bekasi \\ franscy91@gmail.com
}

\begin{abstract}
This research focuses on the analysis of using Google Classroom, Zoom and YouTube as social media applications to learning English. The objective of this research is to know the role of social media (Zoom, Google Classroom and YouTube) for the student's learning achievement at SMA Islam As-Syafi'iyah 01. This research used the descriptive analysis method. The data of this research are questions given to the students using google form and collecting their final score from the English teacher. Then, the result of this research; Most of students (57\% of 100 samples) using their gadgets more than three hours per day. The observation found $96 \%$ of 100 population and from questionnaire got $70 \%$ are always and $19 \%$ are usually using social media for learning. 79,7\% of students said that Google Classroom, Zoom and YouTube are popular and easy to use in language learning. Based on the questionnaire researchers found 53\% are always and $30 \%$ are usually agreed when they must study using Google Classroom, Zoom and YouTube. Researchers found that $18 \%$ of the population are always and the other $48 \%$ are usually got good final scores during online learning using social media. More ever using social media, make students have appropriate platform to study in pandemic era and also can improve their achievement using social media at once.
\end{abstract}

Keywords: Social media; learning English; learning achievement.

\section{INTRODUCTION}

In Indonesia, there have been 1,816,041 confirmed cases of COVID-19 with 50,404 deaths, reported to WHO. As of May 24 2021, a total of 25,455,786 vaccine doses have been administered (WHO Website). It is recommended that the nation ought to have a stricter Stay-at-Home notification, stifle the spread by forcing lockdown for a huge scope, further develop medical care administration, and increment the accessibility of individual defensive hardware.

Nowadays, because of the pandemic era many students have a lot of time with their gadget for online learning. They usually used Google Classroom, Zoom, and YouTube as the application to facilitate their learning process.

In pandemic era teacher have to use technology to provide students to learn. The mechanical advancements in learning English are being utilized concerning students' day by day. The students of English are not difficult to get to a wide scope of assets as far as correspondence with others by technology.

From the early days, assortments of programming and applications, there has been the conversation of how advancements can assume a part in rousing students in learning a language as technologies have become more complex, the developing scope of employments of innovation expands the potential for improved inspiration (Warschauer in Risma, 2021). To make the learning system as agreeable and viable as could be expected, most students pick the appropriately chosen advanced apparatuses for learning.

Computerized devices, online media, and virtual conditions have been widely utilized in working with language instructing and learning. Chun in Amin and Sundari (2020) have noticed that teachers should focus harder on innovation for their classes since it influences language use.

Minton (2014) social media are form of electronic communication. You can use social media to chat with people directly. You can share your ideas and opinions. You can also post messages, photos, videos to show the people in your social network what happenings in your life. 


\section{Google Classroom}

Google Classroom is a Google Apps for Education (GAFE) feature was released on August 12, 2014. Google Classroom is a web-based way of creating virtual classrooms. Google Classroom can be used to transfer assignments, collect them, and even grade them (Shahroom and Hussin, 2018).

Google Classroom is a free option that is available to anyone who creates a Google Application for Education account. Google Classroom is a handy application for online education because it is entirely free and can be used on any device. A feature that adds sophistication to the application is its ability to be used collaboratively in groups. There are several advantages to using Google Classroom as a learning management system. (Soliman, 2014).

\section{Zoom}

One reason video meetings are so successful is that clients can adjust their innovation to suit the gathering objective. For example, specialists and the clinical workforce can now collaborate with patients straightforwardly in their homes through instinctive and dynamic video access with security includes that assist with ensuring patient protections. These clinical experts can send remedies to patients by the best dispatch accessible or to a nearby drug specialist to get their medication straightforwardly. Clinical hardware for far-off checking is turning out to be progressively normal, empowering patients to give information to clinical staff on video calls. Emotional well-being patients can interface with advisors one-onone or take part in bunch directing meetings over video.

Zoom is Simplified video conferencing and informing across any gadget, such as: (1) Unparalleled usability (2) Join anywhere, on any device (3) Powerful meeting security.

\section{YouTube}

YouTube, as referenced, is a promptly accessible wellspring of genuine mainstream society material (Kreisen, 2009). They are empowering understudies to collaborate in an instructive limit with mainstream society through the English language. YouTube clasps might go about as a spurring factor for understudies wishing to additionally foster their language abilities as they try to acquire a more profound comprehension of the substance they eagerly access on the web. In addition, it is additionally accessible for understudies to take part in outside of class some type of understudy focused learning.

Kreisen (2009) Brings up that the inclusiveness of YouTube has empowered understudies to know different societies since the recordings are transferred by many individuals throughout the planet. Moreover, it offers inspiration to the understudies. It likewise permits understudies to do video-sharing, which can give positive yields to learn (Snelson \& Perkins, 2009), furthermore, language learning can occur in a significant environment (Alhamami, 2013). Videos that are transferred can revenue understudies to focus not exclusively on the image yet additionally on the nonverbal motions and pitch which makes the video brimming with lavishness (Stempleski, 2002).

Amin and Sundari (2020) conducted research entitled "The use of technology in language learning during the emergency remote teaching/the Covid-19" The purpose for this research was to decide the students' inclinations, remembering their discernment and perspective for utilizing the stages and application during the distant instructing circumstance. This research applies descriptive qualitative research. In collecting the data this research uses purposive technique sampling.

The research findings shows that the Cisco WebEx Meeting, Google Classroom, and WhatsApp gained highly favorable agreement on all criteria. Specifically, the Cisco WebEx meeting got the highest scores on authenticity and meaning focus.

Based on the explanation above, the 
researchers are interested to analyze "The role of social media on the student's English learning achievement."

\section{METHOD}

In this research, researchers used a qualitative approach with the descriptive analysis method. The researchers chose this method because it is compatible with the study and the researchers need to know that the truth of reality data according to the student's learning achievement in learning process using social media.

Descriptive analysis means to analyze the data which has been described; it is the research based on the fact taken from the transcript of the speech. The investigations in qualitative research worry with understanding the result of discovered information instead of ascertaining the consequence of discovered information (Moleong, 2009).

The Researchers employed descriptive qualitative research with procedure in this research as follows: (1) Collected the data from the source of data. (2) Make an examined result from the data. (3) And made a conclusion of the result analysis (Leroy and Hussin. 2020).

Data in this research was obtained from conducting interviews with the participants by $11^{\text {th }}$ students' grade in SMA Islam As-Syafi'iyah 01, which is supported by a questionnaire to get validity in students' learning achievement when using Google Classroom, Zoom and YouTube as media primarily social used, and documentation as follows the participants' transcript grade list. In this research, the data are collected from Indonesian student.

Comments about the role of the researchers set the stage for the discussion of issues involved in collecting data. The information assortment steps incorporate choosing the limits for the investigation, gathering data through unstructured or semi-organized perception and meetings, archives, and visual materials, just as setting up the convention for recording information.
Subjective perceptions are those in which the researchers take recorded notes on the conduct and exercises of people at the research site. In this case, the researchers record, in an unstructured way (using some preliminary questions that the inquirer wants to know), activities at the researcher site. Qualitative researchers may likewise participate in jobs fluctuating from a non-participant to a complete participant.

During the process of research, the researchers also collecting paper from the participants. The document that researchers used for this research is students' learning achievement report.

The researchers apply descriptive qualitative method to analyze the data by describing or explaining the data from the questioner and the documents. There are some steps in data analysis in this research:

(1) The researchers organized and prepare the data for analysis. This implicated transcribing from the questioner and interview the participant, optically examine material, typing up fields notes and shorting the data.

(2) Read through all the data. A first step is to obtain a general impression of the information and reflect on its comprehensive meaning. Presentation of data generally used in qualitative data is a narrative. Presentations of data accommodate collection of information that organized systematically and obvious to understand.

(3) The conclusion is the last step in data analysis. We must consider the results of data devaluation, keep assign the problem statement in the purpose to be accomplished. Data has been arranged and compared between one and the other. It is to terminated as an answer to the problem. 


\section{RESULTS AND DISCUSSION}

Table 1. Observation

\begin{tabular}{|c|c|c|}
\hline \multirow[t]{2}{*}{ INDICATOR } & \multicolumn{2}{|c|}{ PRESENTATION } \\
\hline & YES & $\mathrm{NO}$ \\
\hline $\begin{array}{l}\text { Students using social } \\
\text { media for learning }\end{array}$ & $100 \%$ & $0 \%$ \\
\hline $\begin{array}{l}\text { Students must join online } \\
\text { learning every section }\end{array}$ & $100 \%$ & $0 \%$ \\
\hline $\begin{array}{l}\text { Students get explanation } \\
\text { from the teacher about } \\
\text { the material. }\end{array}$ & 99\% & $1 \%$ \\
\hline $\begin{array}{l}\text { Students get assignments } \\
\text { using social media }\end{array}$ & $100 \%$ & $0 \%$ \\
\hline $\begin{array}{llr}\text { Students } & \text { doing } & \text { the } \\
\text { assignment } & \text { in } & \text { social } \\
\text { media } & & \end{array}$ & $98 \%$ & $2 \%$ \\
\hline $\begin{array}{l}\text { Students active in English } \\
\text { learning process using } \\
\text { social media }\end{array}$ & $96 \%$ & $4 \%$ \\
\hline $\begin{array}{l}\text { The students still } \\
\text { communicate with the } \\
\text { teacher during the online } \\
\text { learning process }\end{array}$ & $97 \%$ & $3 \%$ \\
\hline $\begin{array}{l}\text { Learning based } \\
\text { guidelines or RPP }\end{array}$ & $78 \%$ & $22 \%$ \\
\hline $\begin{array}{l}\text { Student doing final } \\
\text { assignment during online } \\
\text { learning }\end{array}$ & $98 \%$ & $2 \%$ \\
\hline
\end{tabular}

1. Frequency of social media using in a day. 100 responses

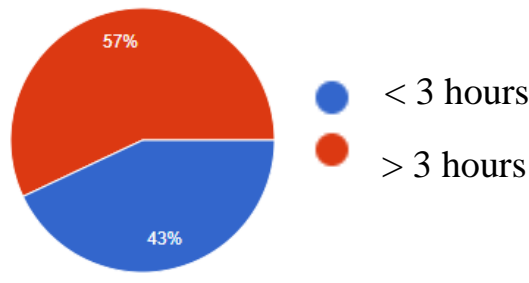

2. Students doing online learning in COVID-19 pandemic era 100 responses

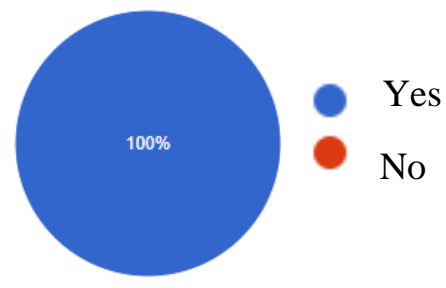

3. Students must join online learning every section. 100 responses

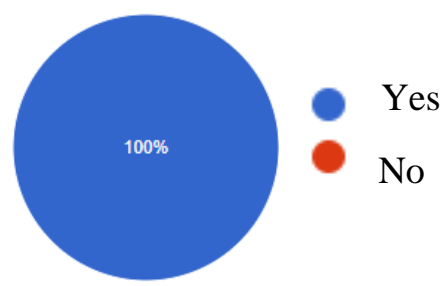

4. Students get an explanation from the teacher about the material 100 responses

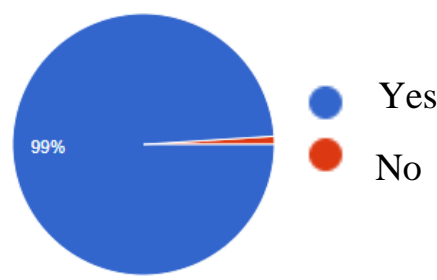

5. Student get assignment using social media (Google Classroom, Zoom and YouTube).
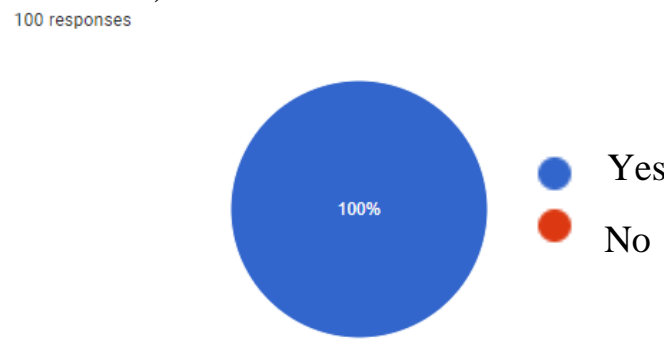

6. Student doing the assignment using social media. (Google Classroom, Zoom and YouTube).

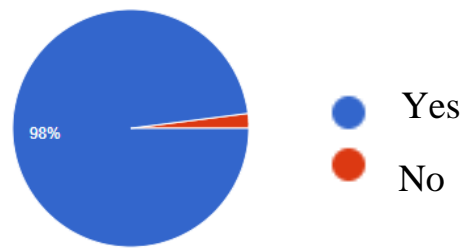


Dialectical Literature and Education Journal (DLEJ)

Volume 6, Issue 1, June 2021

7. Student active in English learning process using social media. (Google Classroom, Zoom and YouTube).

100 responses

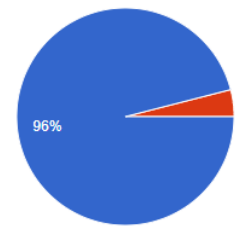

Y Yes

9. Students learning based on guide line or RPP 100 responses
p-ISSN 2548-6926, e-ISSN 2714-996X

https://dlejpancasakti.ac.id/index.php/dlejpancasakt

8. Student still communicate with the teacher during online learning process. 100 responses

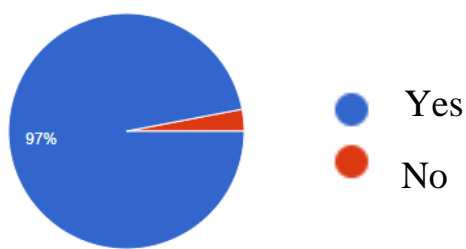

10. Student doing final assignment during online learning.

100 responses

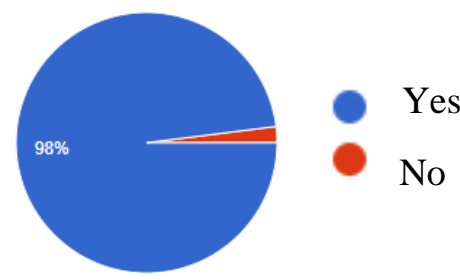

Table 2. Questionnaire

\begin{tabular}{|c|c|c|c|c|c|}
\hline & INDICATOR & ALWAYS & USUALLY & SOMETIMES & NEVER \\
\hline 1. & Do you learn at home in this pandemic era? & $62 \%$ & $20 \%$ & $18 \%$ & $0 \%$ \\
\hline 2. & You are using media electronic for learning & $76 \%$ & $15 \%$ & 9\% & $\mathbf{0 \%}$ \\
\hline 3. & You are using Google Classroom, Zoom and YouTube as social media for learning & $72 \%$ & $21 \%$ & $7 \%$ & $\mathbf{0 \%}$ \\
\hline 4. & Do you agree to learn using Google Classroom, Zoom and YouTube? & $\mathbf{5 2 \%}$ & $\mathbf{2 4 . 7 \%}$ & $18.6 \%$ & $4.1 \%$ \\
\hline 5. & Is social media as Google Classroom, Zoom and YouTube can help you in learning? & $46 \%$ & $35 \%$ & $19 \%$ & $0 \%$ \\
\hline 6. & $\begin{array}{l}\text { Online learning using Google Classroom, Zoom and YouTube can make the English } \\
\text { learning process easier than offline learning. }\end{array}$ & $21 \%$ & $22 \%$ & $40 \%$ & $17 \%$ \\
\hline 7. & You are doing your final test using social media. & $67 \%$ & $25 \%$ & $6 \%$ & $2 \%$ \\
\hline 8. & Students still learns based on schedule every week. & $75 \%$ & $22 \%$ & $3 \%$ & $\mathbf{0 \%}$ \\
\hline 9. & You got an excellent final score during learning using social media. & $18 \%$ & $48 \%$ & $32 \%$ & $2 \%$ \\
\hline 10. & You can explore more when learning using social media. & $40 \%$ & $35 \%$ & $25 \%$ & $0 \%$ \\
\hline
\end{tabular}

1. Do you learn at home in this pandemic era? 100 responses
2. Student using electronic media for learning.

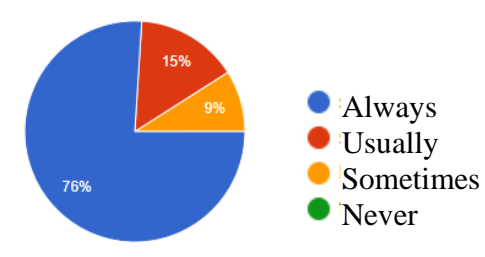


3. You are using Google Classroom, Zoom and YouTube as social media for English learning.

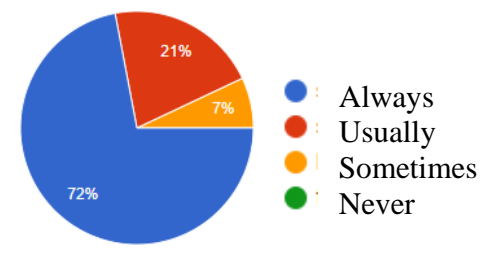

4. Do you agree learning using Google Classroom, Zoom and YouTube? 97 responses

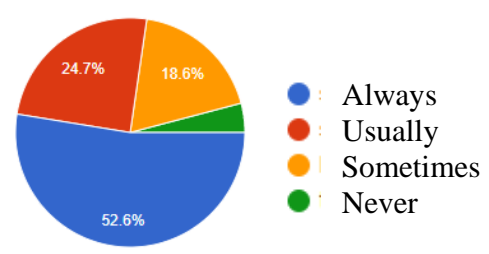

5. Is social media as Google Classroom, Zoom and YouTube can help you in learning?

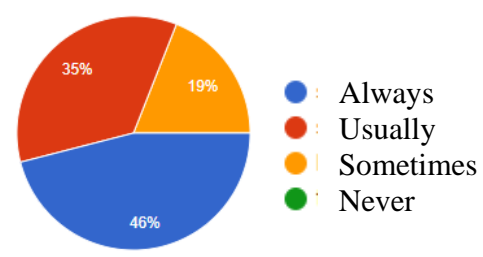

6. Online learning using Google Classroom, Zoom and YouTube can make English learning process easier than offline learning.

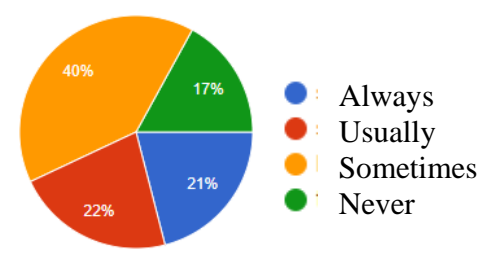

7. You are doing your final test using social media.(Google Classroom, Zoom and YouTube)

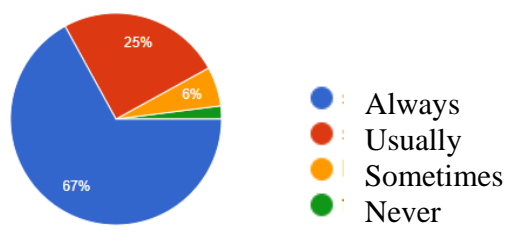

8. Student still learn based on schedule every week.

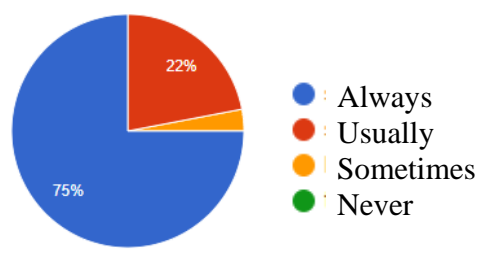

9. You got good final score during learning using social media.

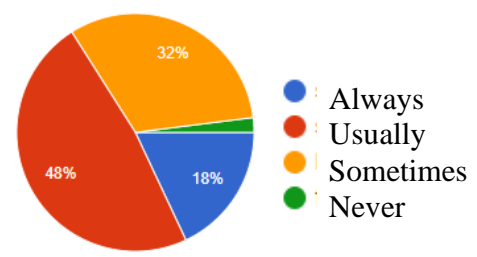

10. You can more explore when learning using social media.

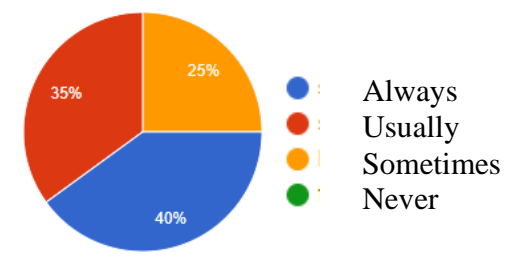

\section{Interview}

1. In a week, how often do you learn English during Online Learning?

I divided the response into three groups of answer.

First group of students said that they learn English one time a week. They learn English just at school when PJJ. They do exercise and learn using social media.

Second group of students said that they learn two or three time per week. They were using social media for learning English.

The third group of students said that they learn English every day because they want to improve their English skills. That group using social media for learn English using their gadget. 
2. Do you agree with using social media for online learning? (Give the reasons)

Most of the students said that they are agree with to learn using social media. They said that they could learn anytime and everywhere they want. Learning English using make them happy because they can more explore and get all information they want.

The other students said that they do not agree when learning using social media. They said that they couldn't learn more effectively. They can more understand the material when the teacher explains it in front of the class.

3. What are your challenging when doing Online English Learning?

Most of the students said that they don't have any challenges when they were doing English online learning. They feel happy because they can improve their English skill based on their own time.

The other student said, their challenge when doing English online learning are the provider connection and about the unpredictable environmental conditions.

4. Write your opinion about using social media when online learning!

Some students said that using social media is very useful because they can repeat the explanation every time, they want making them more understand the material.

The other students said that they are agrees use social media when learning English because they think that they can learn to use any media, especially Google Classroom, Zoom and YouTube. But on another side, they also said that they still need the teacher explanation for learning to make them more understand about the material.

Some other student said that learning English using social media is interesting because they can get a funny explanation when the teacher sent them animation videos for explain the material.
5. Write your English score during PJJ using social media and give your opinion about your score!

Some students get 7-8 for the English score during PJJ using social media. They said that the score they got was good because sometimes they were late to turn in the assignment.

The other students get 8.3 for the average score. They said that it was a good score from the teacher because they knew that they hadn't mastered English as well.

Some other students get 7.5 for the average score. They said that the score is better than offline learning because they have much time to do the assignment and can repeat the explanation every time they want.

\section{Findings \\ The role of social media on student's language learning}

Based on the data in this research, the researchers noticed some student's answer in questionnaire about using social media in English learning process. There are 18 questions related to this explanation. The category of these questions is included the social media they used to learning, how they can get the role of social media in learning, did they think that social media were proper to facilitate students in learning English.

(a) Based on the question "the frequency of using a gadget" most of students $(57 \%$ of 100 samples) using their gadgets for more than three hours per day. They need it, especially to learning in this pandemic era. According to Onwuagboke and Singh (2016), Globalization has gotten its wake many changes and developments in the existence of individuals. One of the impacts is increasing the use of gadgets in student. They need it in for learn and for entertainment.

In online learning student should be able to operate a smart phone and integrate it into their education because that is very useful. In this case student must use social media for learning one time a week for English learning but they can improve their time 
using social media to learn English every time they want. While Salomon and Tekulve and Kelly in Dian (2018) also said about the successful experience in using mobile phones in their libraries in comparison of other social media. Therefore, students can learn English not only in the classroom, but they can also use their smartphones.

(b) The observation found $96 \%$ of 100 population that given to the students are using social media for learning in this pandemic era or we can call it distance learning. The questionnaire got $70 \%$ are always and $19 \%$ are usually using social media for learning. The kind of social media they used for learning are Google Classroom, Zoom and YouTube. In this era, a smartphone is sophisticated tool. Moreover, most students have smartphones with various applications to help them in learning language. In this case Google Classroom, Zoom and YouTube it can be an attractive enterprise for students learning. It can also advise them to receive information whenever they want.

The two main elements of distance learning are pedagogical and technological (Devedžic, 2006). The pedagogical aspect concerns the elearning content; the technological aspect includes e-learning tools that should deliver e-learning content to the students (Yuliya Yurisovna \& Rafisovna Alikberova, 2019; Zabirovna Khabibullina, Mazitovna Akhmedova, Vladislavovich Makletsov, Emitovna Khairullina, \& Ajgul Raisovna, 2019). There are tools for synchronous and asynchronous distant learning. Tools for asynchronous learning consist of reading materials, audio, and video. The synchronous tools include virtual classrooms, webinars and video conferencing.

$79 \%$ of students said that Google Classroom, Zoom and YouTube are attractive and obvious to use in language learning. Based on the questionnaire researcher found $53 \%$ are always and $30 \%$ are usually agreed when they must study using Google Classroom, Zoom and YouTube. There are some advantages that students can get by applying social media. For example, YouTube is one of valuable online device to study languages for students. Moreover, it can engage the students to observe it and replay it every time they want. YouTube provides many kinds of activity. Student can watch, read and listen the audio using YouTube.

The other application is Google Classroom. By using Google Classroom, student can join the class by using class code anywhere and anytime. Google Classroom has unlimited storage. So, they feel Google Classroom is convenient social media to improve their ability on any courses.

Zoom Application is important to help the course of online learning. By using zoom students and teachers can more interactive in English online learning. So, teacher must combine the learning method with the technology for make it the student easier to learn English in online learning. According to Hinneburg et al. (2020), blended learning is a way to combine the technology and innovation offered by online learning with the interaction and participation associated with traditional learning.

\section{Student's learning achievement using social media}

(c) The researchers found that $18 \%$ of the population are always and the other $48 \%$ are usually got good final scores during online learning using social media. Google Classroom, Zoom and YouTube as social media give much development on students. It can inspire them to learn English. It can also give a diverse atmosphere in the learning climate. Students' impression is appropriate and cheerful when they learn using social media. Moreover, it can deliver many information about the material in language learning. The compatible material there can raise students to learn the English language. 
Based on final score data in students' report $78 \%$ of students get better scores when online learning using social media than offline learning classes. Their average score is 80 . They can achieve that because they can repeat the explanation every time they want and they get more variety of activity by using social media. Through the improvement of Google Classroom, Zoom and YouTube, learning using social media can be created to more extensive regions. It is proposed that the students are also extremely simple to get and follow internet learning exercises through the Google Classroom, Zoom and YouTube because it can contain many individuals. It can make students excited and inspired to develop their English learning achievement. As a result, social media can be an expected apparatus for educating and learning (Iftakhar, 2016) also, gets positive fulfillment in the space of access, correspondence and communication (Shaharanee et al., 2016), giving those teachers and student see how to utilize it (Megawati \& Astutik, 2018).

\section{CONCLUSION}

In light of the exploration discoveries and discussion to answer the assertion of issues that have been depicted before, the researchers make it into two points:

1. There are any study habits when using social media for online learning by most eleventh grade students in SMA AsSyafi'iyah 01 especially for learning English. The study habits can be terminated like doing the assignment in social media, active in English learning process using social media, doing final test using social media and communication between students and the teacher using social media in learning.

2. By using Google Classroom, Zoom and YouTube as social media student can learn and more explore when learning using social media. Student get better score when they learn using social media than offline learning. The finding indicates that Google Classroom, Zoom and YouTube as social media are prescribed to be utilized for learning. Social media is important to help the elearning course. It is upheld that the utilization of social media in the learning system can definitely a doubt positive affect expanding students to get better in learning achievement.

\section{REFERENCES}

Alhamami, M. (2013). Observation of Youtube Language Learning Videos (Youtube LLVS). Teaching English with Technology. 13. Retrieved from: https://www.researchgate.net/publication/25 3329214_OBSERVATION_OF_YOUTUB E_LANGUAGE_LEARNING_VIDEOS_Y OUTUBE_LLVS

Amin, F. M., \& Sundari, H. (2020). EFL Students' Preferences on Digital Platforms during Emergency Remote Teaching: Video Conference, LMS, or Messenger Application?. Studies in English Language and Education, 7(2), 362-378. Retrieved from:

http://jurnal.unsyiah.ac.id/SiELE/article/vie $\mathrm{w} / 16929$

Hinneburg, J., J. Luhnen, A. S., and Berger, H. (2020). A Blended Learning Training Programme for Health Information Providers to Enhance Implementation of The Guideline Evidence-Based Health Information: Development and Qualitative Pilot Study. BMC Med Educ 20(1):77. Retrieved from: https://bmcmededuc.biomedcentral.com/arti cles/10.1186/s12909-020-1966-3

Iftakhar, S. (2016). Google Classroom: What Works and How. Journal of Education and Social Sciences, 3(1), 12-18. Retrieved from: https://jesoc.com/wpcontent/uploads/2016/03/KC3 35.pdf

Lutfiani, D. (2018). The Use of Gadget on Students' Study Habit in English Language Learning at SMA An-Najiyah Surabaya (Doctoral dissertation, UIN Sunan Ampel Surabaya). Retrieved from: http://digilib.uinsby.ac.id/id/eprint/28760

Megawati, F., \& Astutik, Y. (2018). EFL Learning Media: Perspective on E-Learning through Google Classroom [Paper presentation]. Proceedings of the 1st 
International Conference on Emerging Media, and Social Science, ICEMSS 2018, Banyuwangi, Indonesia (pp. 1-6). European Alliance for Innovation. Retrieved from: https://eudl.eu/doi/10.4108/eai.7-122018.2281768

Minton, E. (2014). Social Networking and Social Media Safety. America: Windmill Books.

Moleong, L. (2009). Metodologi Penelitian Kualitatif. Bandung: PT. Remaja Rosdakarya

Onwuagboke, B. \& Singh, T. K. (2015). Faculty Attitude and Use of ICT in Instructional Delivery in Tertiary Institutions in a Developing Nation. International Journal of Research Studies in Educational Technology. 5. 10.5861/ijrset.2016.1428. Retrieved from:

https://www.researchgate.net/publication/29 7650673 Faculty attitude and use of ICT in instructional delivery in tertiary instit utions in a developing nation

Risma, S. N. (2021). An Analysis of The Utilizing Zoom Application to English Learners' speaking Skill Motivation. PROJECT (Professional Journal of English Education), 4(3), 433445. Retrieved from: https://journal.ikipsiliwangi.ac.id/index.php/ project/article/view/6594

Shaharanee, I. N. M., Jamil, J. M., \& Rodzi, S. S. M. (2016). Google Classroom as a Tool for Active Learning. AIP Conference Proceedings, 1761, 1-7.

Shahroom, A. A. and Hussin. (2018). Industrial Revolution 4.0 and Education. International Journal of Academic Research in Business and Social Sciences 8(9):314-319.

Siahaan, L. H., \& Hussin, A. (2020). An Analysis Code Mixing on The Video of Mr. Nadiem
Makarim's Meeting. Dialectical Literature and Educational Journal, 5(2), 59-65.

Snelson, C., \& Perkins, R. (2009). From Silent Film to YouTube ${ }^{\mathrm{TM}}$ : Tracing the Historical Roots of Motion Picture Technologies in Education. Journal of Visual Literacy, 28, 1 - 27.

Soliman, N. (2014) Using E-Learning to Develop EFL Students' Language Skills and Activate Their Independent Learning. Creative Education, 5, 752-757. doi: 10.4236/ce.2014.510088. Retrieved from:

https://www.scirp.org/pdf/CE_2014061914 552845.pdf

Stempleski, S. (2002). Video in the ELT Classroom: The Role of the Teacher. In J. C. Richards \& W. A. Renandya (Eds), Methodology in Language Teaching (pp. 364- 366). Cambridge: Cambridge University Press.

Yuliya Y. K. \& Rafisovna, A. A. (2019). An Investigation of Factors Affecting the Russia and Korea Student Satisfaction: The Cases of Language and Culture. Journal of Research in Applied Linguistics, 10(Proceedings of the 6th International Conference on Applied Linguistics Issues (ALI 2019) July 19-20, 2019, Saint Petersburg, Russia), 1289-1299. doi: 10.22055/rals.2019.15372. Retrieved from: https://rals.scu.ac.ir/article_15372.html

Zabirovna K. et. al. (2019). On the Effectiveness of the Training Programs in the Learning Process. Journal of Research in Applied Linguistics, 10 (Proceedings of the 6th International Conference on Applied Linguistics Issues (ALI 2019) July 19-20, 2019, Saint Petersburg, Russia), 590-597. doi: 10.22055/rals.2019.15104 